\title{
Acacia sieberiana Effects on Soil Properties and Plant Diversity in Songa Pastures, Rwanda
}

\author{
C. P. Mugunga ${ }^{1}$ and D. T. Mugumo ${ }^{1,2}$ \\ ${ }^{1}$ National University of Rwanda, P.O. Box 56, Huye, Rwanda \\ ${ }^{2}$ Universite Libre de Kigali, Rubavu Campus, P.O. Box 243, Gisenyi, Rwanda \\ Correspondence should be addressed to C. P. Mugunga; mugungac@yahoo.co.uk
}

Received 3 July 2013; Accepted 9 September 2013

Academic Editor: Curtis C. Daehler

Copyright (c) 2013 C. P. Mugunga and D. T. Mugumo. This is an open access article distributed under the Creative Commons Attribution License, which permits unrestricted use, distribution, and reproduction in any medium, provided the original work is properly cited.

\begin{abstract}
Effects of A. sieberiana trees on soil properties and plant diversity were investigated in Songa pastures, Rwanda. Tree characteristics and crown architecture of $A$. sieberiana were studied. Soil properties were assessed and plants were identified under and away from tree crowns. Counts of individual plants/species were done only under tree crowns. Nitrogen, P, and $\mathrm{K}$ were analysed in the soil, grass, and A. sieberiana leaves. Plant diversity was determined using Simpson's diversity index. Data were subjected to ANOVA. Soil organic carbon (SOC), cation exchange capacity (CEC), $\mathrm{Ca}^{2+}, \mathrm{N}$ and $\mathrm{pH}$, and plant diversity were higher in soils under tree canopies than in open areas. Tree leaves were significantly richer in $\mathrm{N}$ and poorer in $\mathrm{P}$ and $\mathrm{K}$ as compared to grasses. Tree crowns grew wider and horizontal and developed intertwined secondary branching, reducing light intensity to as low as $38 \%$ under tree canopies compared to the open pasture. At 3 trees/ha stocking, A. sieberiana trees shaded 0.18 ha and herbaceous plants and grasses unpalatable to livestock dominated under tree canopies. A tradeoff of $A$. sieberiana tree value versus the loss of palatable grass due to tree presence needs to be assessed to decide whether the trees should be included in pastures and if yes, the apporpriate stocking identified.
\end{abstract}

\section{Introduction}

The incorporation or retention of trees into farming systems is an old tradition in Africa. This makes a basis of what is often referred to as agroforestry [1]. Trees in such systems fulfil a lot of functions and services [2]. They may provide shelter to soils, plants, and livestock and may increase soil organic matter and sometimes soil nitrogen content. Being perennial, tree functions and their influence on the site may be cumulative [3]. A few or a group of trees are usually left deliberately or planted on land under some other main use in which case trees fulfil a secondary role [4].

It is well known that some trees may deplete soil resources and this is more severe with some exotic species, for example, Eucalyptus [5], which compete with other plants for soil moisture [5-7] and for soil nutrients [8-10]. More often, some tree species negatively interfere with biodiversity, leading to a decline in plant diversity [11]. This tendency is sometimes attributed to allelopathy [12-14]. Some plant species may improve soil properties [15] and yet deplete biodiversity. Even the best trees in soil improvement may be detrimental to biodiversity, especially when planted at a narrow spacing where the reduction in the amount of light reaching the ground may suppress shade intolerant plants [16].

Trees capture and return leached nutrients to the crops' rooting zone [17] through processes known as the safety net [18] and the nutrient pump [19], respectively. In doing so they can affect soil $\mathrm{pH}$ by reducing or increasing it depending on tree species. Ryan and McGarity [20] found that $\mathrm{pH}$ decreased under Eucalyptus grandis canopies. Increase in soil $\mathrm{pH}$ is clearly significant for production, as Munnich et al. [21] found that the frequency of the nutritious and palatable native grass Microlaena stipoides increased with lower soil $\mathrm{pH}$.

Acacia species in general are multipurpose trees providing a wide range of products and services [22]. The tree is socially accepted because it provides fuel, fodder, gum, and local medicine to farmers among others. A. sieberiana is reported to be one of the most commonly used browse tree 
species in arid and semiarid regions of Africa $[23,24]$ as it has good feeding qualities. Indices among other factors include the species' low insoluble proanthocyanidins and high soluble phenolics [25]. Soils under a variety of tree species are often higher in nitrogen, phosphorus and other nutrients [26-29]. Acacia litter contributes greatly to soil fertility due to the tree's ability to fix atmospheric nitrogen [30]. In arid and semiarid areas, the soils beneath the Acacia canopy are usually better developed than those outside the canopy, having higher nitrogen and water contents [31]. Nitrogen fixing ability of the tree makes it one of the most suitable species for agricultural fields [32].

In Rwanda, Acacia sieberiana remnant trees are left in pastures for shade or fodder or planted in home gardens for ornamental purposes [33]. Managed pasture has emerged as an important land use system in the postgenocide period. Although animal rearing in pastures is more prominent in the savannah woodlands of the eastern province, it is practiced in other parts of the country as well. Changes in land use have recently led to a profound reduction in woodland structure and tree cover where tree patches or individual trees which have survived tree cutting are seen in pastures, in crop farms, and in home gardens. One of the most remarkable tree species which can be seen in pastures is Acacia sieberiana DC.

Despite their acknowledged benefits, there is no management plan or clear policy guidelines on the management of such trees or their impacts on the main features of site characteristics, particularly the soil and biodiversity. This is because they have not been studied for their influence on soil characteristics and plant diversity under pasture management, at least under local conditions. Furthermore, the architecture of $A$. sieberiana's crown is very low and very broad, imparting a significant shading effect to the ground and plants underneath its canopy. The aim of this study was to assess the crown architectural characteristics of $A$. sieberiana trees and the resultant shading effects and the influence on soil properties and plant diversity in Songa pasture, southern Rwanda. The results may then be applied to the pastures in the eastern province, a region which has a higher population of $A$. sieberiana trees in similarly managed pastures.

\section{Materials and Methods}

This study was conducted at the Songa Research Station of the Rwanda Agriculture Board from December 2011 to March 2012. According to Manzi et al. [34], the station is located in the mid-altitude zone (1500-1600 masl) of Rwanda $\left(2^{\circ} 24^{\prime} \mathrm{S}, 29^{\circ} 46^{\prime} \mathrm{E}\right)$, with average annual temperature ranging between $22^{\circ} \mathrm{C}$ and $29^{\circ} \mathrm{C}$, an average annual rainfall of $1087 \mathrm{~mm}$ (1237 $\mathrm{mm}$ according to [35]), and relative humidity of $77 \%$. The rainfall pattern is bimodal, with short rains (season A) falling between September and December and long rains (season B) extending from March through May. The dry season extends between June and August, sometimes to September. The rain is heavy in April-May, decreasing gradually until October. The natural vegetation consists of natural grass dominated by Brachiaria decumbens. The pasture is scattered by trees of $A$. sieberiana traditionally used to supply shade to the livestock during hot days.
Soil sampling and plant identification were done in systematically demarcated plots. For this purpose, the whole pasture was divided into four blocks and four A. sieberiana trees were randomly selected in each block to make a total of 16 sample trees. Circular sample plots of $1 \mathrm{~m}$ diameter each were laid $3 \mathrm{~m}$ apart along two perpendicular transects running from each $A$. sieberiana tree trunk to the periphery of the crown in north and east directions. Of the 16 sample trees, 10 trees had 10 sample plots each and six trees had eight plots each, giving a total of 148 sampling points that were used for soil sampling and plant counts under tree canopies.

From the sample trees, four traits were measured, namely, breast height diameter $(\mathrm{DBH})$, crown diameter $(K)$, heightto- crown base $\left(H_{\mathrm{CB}}\right)$, and branch tip height above the ground $\left(H_{\mathrm{BT}}\right)$. Individual tree $\mathrm{DBH}$ was measured using a diameter tape. A tape measure was used to measure $K$ as the diameter of the crown shade projected to the ground when the sun was overhead at noon. From the latter, the area shaded by the crown $(A)$ was computed as the area of a circle whose diameter equals $K . H_{\mathrm{CB}}$ and $H_{\mathrm{BT}}$ were measured by using a tape measure by putting its zero end on the ground and stretching it to the base of the branch and to the tip of the branches, respectively. For measuring $H_{\mathrm{CB}}$ and $H_{\mathrm{BT}}$, four lower branches attached to the main stem in approximately four cardinal directions were taken in each sample tree. To get more insight on the branching characteristics of the species, extra assessments were made. One tree was selected per block and the following traits were measured: $K$, total tree height $\left(H_{\mathrm{TOT}}\right), H_{\mathrm{CB}}$, and $H_{\mathrm{BT}}$. During growth, A. sieberiana tree branches usually undergo a series of successive deaths followed by development of new or secondary branches. Secondary branch lengths (internodes) $\left(L_{I}\right)$ per branch were measured using a tape measure, done by climbing the tree using a ladder and measuring the length of the branch part between two death (and regrowth) points. This enabled us to get the total count of internodes/branch $\left(N_{I}\right)$ and the sum of all $L_{I}$ /branch gave the total branch length $\left(L_{\mathrm{Br}}\right)$.

To assess the intensity of shade by $A$. sieberiana trees, the amount of light was measured both under and outside the tree canopies. For this purpose, the four sample trees used for extra tree trait measurements said above were used. LICOR quantum sensors (LI-COR 1000) were laid along the transects explained above from the tree base to $30 \mathrm{~m}$ which is about double the crown radius. Six sensors were spaced at five meters such that three were under the tree canopy at the tree base $(0 \mathrm{~m})$, at mid crown $(7.5 \mathrm{~m})$, and at the crown periphery $(15 \mathrm{~m})$ while the other three were located in the open pasture at 20,25, and $30 \mathrm{~m}$ away from the tree base. Assessments were made for three consecutive days from August 7-9, 2013, and from each sensor, readings were taken six times per day at 6 , $8,10,12,14,16$, and $18 \mathrm{~h}$. This period is the dry season, which is characterized by very little cloud cover. Light measurements were recorded as photosynthetic photon flux density (PPFD) $\left(\mu \mathrm{M} \mathrm{m}^{-2} \mathrm{~s}^{-1}\right)$.

In order to compare plant species that occurred under and away from the tree crowns and the effect of $A$. sieberiana trees on soil chemical and physical properties, plant identification and soil sampling were also done in the area under grass outside the tree crowns. Transects explained above were 
extended to double their length such that $1 / 2$ the transect length was covered by the $A$. sieberiana crown while the other $1 / 2$ was outside the tree crown. In this extended distance outside the tree crowns, sampling points similar and equal in size and number to those demarcated under the tree crowns were established.

For all soil sample collection, sampling was done in the top $(0-10 \mathrm{~cm})$ soil layer using an auger. All plant species occurring in the plots both under and away from the crowns were botanically identified, but a physical count of individuals per species was done only in the plots under the tree crowns. Soil parameters of interest included particle size distribution, soil organic carbon (SOC), exchangeable calcium $\left(\mathrm{Ca}^{2+}\right)$, and soil pH. Soil and foliar nutrient analyses were done using standard procedures as explained by Okalebo et al. [36]. Leaf nutrients tested included total N, P, and $\mathrm{K}$.

For statistical analyses, all measured variables were subjected to an analysis of variance to assess differences between treatments. Levene's test was used to test for homogeneity of variance. Statistical significance was determined at $P<$ 0.05 and differences among treatments were separated using the LSD test. All analyses were performed using SPSS 17.0 software for Windows. Biodiversity was determined by using Simpson's index of diversity (1D).

\section{Result and Discussion}

3.1. Soil Properties. The sand proportion was significantly higher $(P<0.05)$ away from $A$. sieberiana canopy $(70 \%)$ than under the canopy (65\%) (data not presented). This difference might be due to a positive contribution of the trees to soil improvement, owing to leaf litter and root turnover. Litter addition usually improves soil aggregate stability by binding soil particles together [37]. Furthermore, the soil outside the tree canopies dries out faster as a result of being more exposed to direct solar radiation. This not only accelerates thermally induced soil organic matter decomposition but also results in the shrinking of organic matter and clay colloids, thereby making the soil more compact [38].

Results of soil chemical properties are shown in Table 1. Soil pH, soil N, SOC, and $\mathrm{Ca}^{2+}$ improved significantly under the canopy probably due to the presence of A. sieberiana trees. The overstory may facilitate forage species, for instance, by improving soil conditions, as for crops in agroforestry [39]. This is in agreement with the findings by Sirois et al. [40]. Generally speaking, all soils of Rwanda have a low $\mathrm{pH}$ [41, 42 ] and this condition limits nutrient availability [43]. The incorporation of trees in farming systems as sources of litter partly aims at increasing soil $\mathrm{pH}$. This has been one of the major practices in agroforestry systems [44]. A. sieberiana, as trees that have been standing in the study area for a long time, may have significantly contributed to the improvement in soil $\mathrm{pH}$ and other soil properties.

The accumulation of organic matter and nutrients in the soils under tree canopies as found in this study might have several origins. These may include litter falling from the trees, root turnover, animal defecation as they stay under shade for browsing and/or rest during hot periods, and decay of shade tolerant plants that grow prolifically under the canopy $[22,37$, $45,46]$.

3.2. Tree Sizes and Crown Shade. The total pasture area was 310 ha and the average stocking was $3 \mathrm{~A}$. sieberiana trees/ha. All trees in the study area were mature and neither seedlings nor saplings were observed. Average tree traits were observed to be: $148.3 \mathrm{~cm}$ for DBH (range: 100.6-180.0 cm), $27.7 \mathrm{~cm}$ for $K$ (range: $21.4-34.0 \mathrm{~m}$ ), 0.061 ha for $A$ (range: $0.036-$ $0.091 \mathrm{ha}$ ), $3.4 \mathrm{~m}$ for $H_{\mathrm{BC}}$ (range: $1.8-5.4 \mathrm{~m}$ ), and $2.5 \mathrm{~m}$ for $H_{\mathrm{BT}}$ (range: 1.5-4.1 m). Traits related to the crown architecture are shown in Table 2. Tree sizes reported here are within the range reported for the species [47]. It should be noted here that branch length is the summation of all internode lengths per branch and these are directly linked to $K$.

A. sieberiana trees shade a big ground area under tree canopies. The pasture area shaded by an average $A$. sieberiana tree was observed to be 0.06 ha. The shading capacity was observed to be a result of such architectural characteristics of the crown as the size, branch network, and the height above the ground. The tree is characterised by low branching and its branches experience successive death of branch tips followed by the development of one or more secondary branches (internodes) emanating in different directions from the previous death point. This process leads to the development of a twined branch network which, together with tall branches ( $L_{\mathrm{Br}}$ of about $10-16 \mathrm{~m}$ ), constitutes a broad crown. Usually the secondary branch height (and therefore the crown height) above the ground increases from near the branch base (at 1$5 \mathrm{~m}$ ) to a certain maximum at about half the branch length. The height then drops outwards to the tip of the branch ending up with a branch tip height $(1.5-4 \mathrm{~m})$ equal to or less than the branch base. This leads to naturally very low and flattened tree crowns which appear as mushroom- or umbrella-like shapes in A. sieberiana.

This crown architecture causes a strong shading effect on the ground underneath tree canopies. The light levels at $0,7.5$, and $15 \mathrm{~m}$ from the tree base were found to range from 38,60 to $85 \%$ (average $61 \%$ ), respectively, of the values in the open pastures. The three distances corresponded to middle, halfway, and the periphery of A. sieberiana tree crown from the tree base (Table 3). While a mesh-like network of its branches alone could suffice to keep the area under its crown shaded even if all the leaves were shed, the tree sheds only a small proportion of its leaves during the dry seasons rendering it to remain evergreen all year round. These facts make it an effective shelter tree to livestock especially in arid and semiarid areas during the dry seasons.

The photosynthetic photon flux density (PPFD) recorded under the tree canopy $\left(328-746 \mu \mathrm{M} \mathrm{m}^{-2} \mathrm{~s}^{-1}\right)$ and in the open pastures in this study $\left(857-878 \mu \mathrm{M} \mathrm{m}^{-2} \mathrm{~s}^{-1}\right)$, even at points furthest $(30 \mathrm{~m})$ from the tree base, is lower than the normal range for full light which normally ranges from 1200 to $2000 \mu \mathrm{M} \mathrm{m}^{-2} \mathrm{~s}^{-1}$ [48]. Light levels recorded in this study are only slightly higher than those reported under agroforest canopy, said to be usually around $800 \mu \mathrm{M} \mathrm{m}^{-2} \mathrm{~s}^{-1}$ [48] except under highly closed forests where light can be as low as $50 \mu \mathrm{M} \mathrm{m}^{-2} \mathrm{~s}^{-1}[49,50]$. 
TABLE 1: Chemical characteristics of the top $(0-10 \mathrm{~cm})$ soil layer under and outside the canopies of Acacia sieberiana trees in Songa pasture, southern Rwanda.

\begin{tabular}{lccc}
\hline Soil properties & Means under tree canopy $(n=48)$ & Means under open area $(n=48)$ & \\
\hline $\mathrm{pH}$ & $5.79 \pm 0.13$ & $5.44 \pm 0.08$ & \\
$\mathrm{~N}(\%)$ & $0.90 \pm 0.06$ & $0.63 \pm 0.05$ & $*$ \\
$\mathrm{C}(\%)$ & $4.76 \pm 0.31$ & $3.63 \pm 0.29$ & \\
$\mathrm{P}(\mathrm{ppm})$ & $45.01 \pm 5.72$ & $31.54 \pm 4.14$ & \\
$\mathrm{Ca}^{2+}$ & $9.81 \pm 0.55$ & $4.14 \pm 0.56$ & $\mathrm{NS}$ \\
$\mathrm{K}^{+}$ & $0.46 \pm 0.03$ & $0.58 \pm 0.09$ & \\
$\mathrm{Mg}^{2+}$ & $1.91 \pm 0.10$ & $1.94 \pm 0.21$ & \\
\hline
\end{tabular}

${ }^{*}$ and NS denote, respectively, significant and nonsignificant differences among means for soils under and away from tree crowns $(P<0.05)$.

TABLE 2: Acacia sieberiana crown architecture: crown diameter $(K)$, total tree height $\left(H_{\mathrm{TOT}}\right)$, height from the ground to the crown base $\left(H_{\mathrm{CB}}\right)$, height from the ground to the branch tip $\left(H_{\mathrm{BT}}\right)$, branch length $\left(L_{\mathrm{Br}}\right)$, branch internode length $\left(L_{I}\right)$, and the number of internodes/branch $\left(N_{I}\right)$ in Songa pastures, southern Rwanda.

\begin{tabular}{|c|c|c|c|c|c|c|c|c|}
\hline Tree no. & Branch no. & $K(\mathrm{~m})$ & $H_{\text {Tot }}(\mathrm{m})$ & $H_{\mathrm{CB}}(\mathrm{m})$ & $H_{\mathrm{BT}}(\mathrm{m})$ & $L_{\mathrm{Br}}(\mathrm{m})$ & $L_{I}(\mathrm{~m})$ & $N_{I}$ \\
\hline \multirow{4}{*}{1} & 1 & \multirow{4}{*}{24.6} & \multirow{4}{*}{6.1} & \multirow{4}{*}{5.1} & 0.9 & 15.2 & 1.1 & 15 \\
\hline & 2 & & & & 1.5 & 11.5 & 0.6 & 18 \\
\hline & 3 & & & & 2.2 & 12.8 & 1.0 & 16 \\
\hline & 4 & & & & 2.0 & 12.6 & 0.6 & 20 \\
\hline \multirow{4}{*}{2} & 1 & \multirow{4}{*}{27.2} & \multirow{4}{*}{8.1} & \multirow{4}{*}{3.0} & 1.3 & 15.7 & 1.1 & 16 \\
\hline & 2 & & & & 5.2 & 15.8 & 0.9 & 18 \\
\hline & 3 & & & & 5.3 & 12.5 & 0.9 & 18 \\
\hline & 4 & & & & 3.1 & 9.7 & 0.5 & 20 \\
\hline \multirow{4}{*}{3} & 1 & \multirow{4}{*}{24} & \multirow{4}{*}{7.8} & \multirow{4}{*}{1.0} & 2.6 & 13.1 & 1.0 & 19 \\
\hline & 2 & & & & 1.5 & 15.7 & 1.0 & 19 \\
\hline & 3 & & & & 1.4 & 14.4 & 1.0 & 18 \\
\hline & 4 & & & & 1.7 & 15.8 & 0.9 & 17 \\
\hline \multirow{4}{*}{4} & 1 & \multirow{4}{*}{26.9} & \multirow{4}{*}{6.9} & \multirow{4}{*}{4.4} & 2.1 & 15.0 & 0.8 & 19 \\
\hline & 2 & & & & 1.3 & 11.4 & 0.6 & 18 \\
\hline & 3 & & & & 1.6 & 10.3 & 0.5 & 19 \\
\hline & 4 & & & & 1.4 & 9.7 & 0.5 & 20 \\
\hline \multicolumn{2}{|c|}{ Average } & 25.7 & 7.2 & 3.4 & 2.2 & 18.1 & 13.2 & 0.8 \\
\hline \multicolumn{2}{|c|}{ Range } & $24.0-27.2$ & $6.1-8.1$ & $1-5.1$ & $0.9-5.3$ & $9.1-15.8$ & $0.5-1.1$ & $15-20$ \\
\hline
\end{tabular}

High shading intensity is, however, not always beneficial since it may influence the microclimate and hence the soils and biodiversity under the tree crowns [11, 16]. At an average stocking rate of 3 trees/ha observed in this study, a corresponding area shaded by the crown was 0.183 ha, an $18 \%$ of a hectare. With an observed tendency of unpalatable plant species growing under A. sieberiana trees (Table 5) and assuming a uniform production rate of grasses throughout the pasture, a stocking of 3 A. sieberiana trees/ha would lead to $18 \%$ reduction in the yield of palatable grasses.

A. sieberiana trees are usually used as fodder for animals and they become more important in dry seasons and more so in arid regions when shelter to animals is of great value and grasses in the pastures decline significantly in quantity and in quality [23]. A. sieberiana is reported to have higher crude protein than a number of other species [51]. It could be possible that fodder value of $A$. sieberiana trees may compensate for losses in palatable grass yield resulting from growing or retaining the trees in pastures. This however needs to be ascertained through research. The study area however is reasonably wet and cool and the importance of shelter may not be that important. In addition, fodder harvesting from Acacia trees may not be an easy undertaking since young branches with pods and tender leaves need to be cut every time they have to be supplied to the animals as fodder.

3.3. Foliar Analysis. The quantities of the major nutrients $(\mathrm{N}$, $\mathrm{P}$, and $\mathrm{K}$ ) obtained through folia analyses are presented in Figure 1. As would be expected, significant differences $(P<$ 0.05 ) were observed in nitrogen contents in A. sieberiana tree leaves compared to the grasses outside the tree influence, with a higher nitrogen percentage being observed in tree leaves than in the grasses. An inverse situation was observed for potassium which was significantly $(P<0.05)$ more concentrated in grasses than in $A$. sieberiana tree leaves. Phosphorus had slightly higher values in grasses than in trees, but did not differ statistically from those obtained in A. sieberiana leaves. 
TABLE 3: Light intensity measured at six locations $(0,7.5,15,20,25$, and $30 \mathrm{~m})$ from Acacia sieberiana tree base in Songa pasture southern Rwanda. Upper table shows measurements expressed as \% of light relative to open pasture; lower table measurements are expressed as photosynthetic photon flux density $\left(\mu \mathrm{M} \mathrm{m}^{-2} \mathrm{~s}^{-1}\right)$.

\begin{tabular}{|c|c|c|c|c|c|c|}
\hline \multirow{2}{*}{ Time } & \multicolumn{6}{|c|}{ Sensor identity (distance from tree base, $\mathrm{m}$ ) } \\
\hline & $1(0)$ & $2(7.5)$ & $3(15)$ & $4(20)$ & $5(25)$ & $6(30)$ \\
\hline 6:00 & 38.4 & 62.6 & 84.8 & 99.4 & 97.3 & 100.0 \\
\hline 8:00 & 39.3 & 60.0 & 83.6 & 98.7 & 99.2 & 100.0 \\
\hline 10:00 & 35.7 & 61.5 & 84.1 & 95.4 & 96.0 & 100.0 \\
\hline 12:00 & 37.2 & 68.2 & 85.3 & 99.4 & 99.9 & 100.0 \\
\hline 14:00 & 37.2 & 60.1 & 88.3 & 98.4 & 99.9 & 100.0 \\
\hline $16: 00$ & 37.7 & 60.1 & 81.0 & 98.5 & 100.2 & 100.0 \\
\hline 18:00 & 38.0 & 45.5 & 85.9 & 93.5 & 99.7 & 100.0 \\
\hline \multirow{2}{*}{ Average } & 37.6 & 59.7 & 84.7 & 97.6 & 98.9 & 100.0 \\
\hline & & $60.7^{*}$ & & \multicolumn{3}{|c|}{$98.8^{* *}$} \\
\hline $6: 00$ & 215.4 & 351.2 & 475.5 & 557.4 & 545.6 & 560.7 \\
\hline $8: 00$ & 265.3 & 405.5 & 564.7 & 666.9 & 670.3 & 675.5 \\
\hline $10: 00$ & 373.5 & 642.4 & 878.8 & 997.6 & 1003.1 & 1045.2 \\
\hline $12: 00$ & 470.6 & 862.4 & 1078.8 & 1257.2 & 1262.4 & 1264.2 \\
\hline $14: 00$ & 463.5 & 748.9 & 1101.4 & 1227.4 & 1245.7 & 1246.9 \\
\hline $16: 00$ & 299.3 & 477.7 & 643.6 & 782.4 & 795.6 & 794.4 \\
\hline 18:00 & 211.6 & 253.5 & 478.5 & 521.2 & 555.5 & 557.3 \\
\hline \multirow{2}{*}{ Average } & \multirow[t]{2}{*}{328.5} & 534.5 & \multirow[t]{2}{*}{745.9} & \multirow[t]{2}{*}{858.6} & 868.3 & \multirow[t]{2}{*}{877.7} \\
\hline & & $536.3^{*}$ & & & $868.2^{* *}$ & \\
\hline
\end{tabular}

Overall average light: ${ }^{*}$ under tree canopy and ${ }^{* *}$ in open pasture.

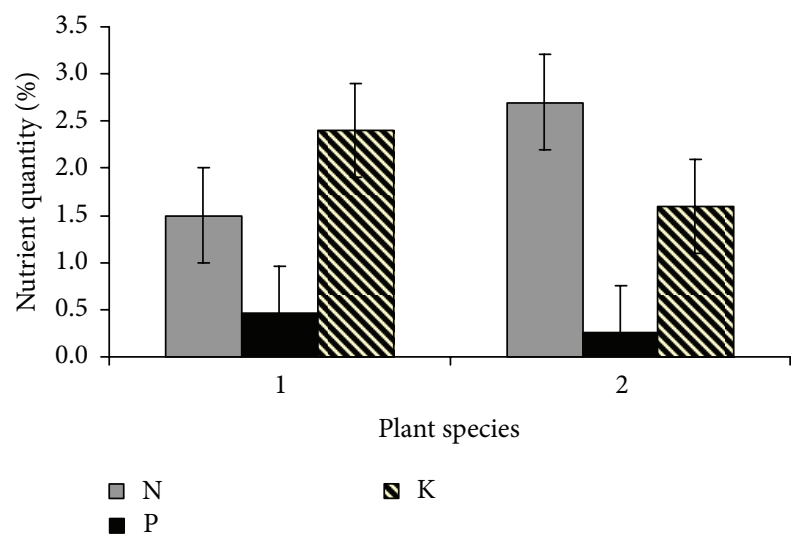

FIgURE 1: Nitrogen, $\mathrm{P}$, and $\mathrm{K}$ (\%) obtained from species 1 (grass) and from species 2 (A. sieberiana) leaves in Songa pastures, southern Rwanda. Vertical bars represent standard errors of the means $(n=$ 48).

The higher concentration of nitrogen in A. sieberiana tree leaves than in grass is presumably due to the ability of many acacias to fix atmospheric nitrogen [52]. This attribute makes them suitable for agricultural fields and for incorporation in agroforestry systems [32]. The lack of statistical differences between tree and grass leaves in phosphorus content may not be surprising. Both Acacia and grasses are known to live in association with vesicular arbuscular mycorrhizal fungi (VAM) [4].
3.4. Plant Diversity. Plants that grew under A. sieberiana tree canopy were mainly herbaceous, differed in life forms, and were easy to separate and count, while those which grew outside the canopy were dominated by Brachiaria grass and were not easy to sort out individually (Figure 2). Niche preference differed between plant species and some plants were exclusively found either under the tree canopy or outside the tree canopy while others were common in both niches (Table 4). For the species that occurred exclusively under $A$. sieberiana tree canopy, the average number of individuals per species ranged from 0.1 to 693 (Table 4). Setaria homonyma, the only grass species in this group, had the highest number followed by Tagetes minuta and the rest of the species had very low numbers of individuals per species (Table 5). Like all plant species identified under $A$. sieberiana tree canopy, $S$. homonyma was unpalatable to the cattle.

Overstory competition is reported to reduce forage production in the understory $[53,54]$. In addition, constraining the light and nutrients available to the understory could shift plant composition toward species tolerant of shade and nutrient stress [55]. Stress tolerant species tend to have "conservative" life history strategies emphasizing conservation of resources over rapid growth, while fast-growing "acquisitive" species often require productive conditions [56]. Reduced photosynthetic and growth rates of conservative species are usually associated with low nutrient content [57] and high content of structural and defensive compounds [58] such as lignin that can moreover reduce their quality as forage [59, 60]. Plant species interactions change with environmental condition, and can shift over time as conditions change. For 
TABle 4: Species and families found in Songa pasture, southern Rwanda (data collected from 148 sample plots under A. sieberiana tree canopies and from 148 plots outside the tree canopy area).

\begin{tabular}{|c|c|c|}
\hline No & Botanical name & Family \\
\hline 1 & Acacia sieberiana DC. ${ }^{*}$ & Mimosoideae \\
\hline 2 & Achyranthes aspera L. ${ }^{*}$ & Amaranthaceae \\
\hline 3 & Aspilia pluriseta Schweinf. ${ }^{* * *}$ & Asteraceae \\
\hline 4 & Asystasia gangetica (L.) T. Anders. ${ }^{* *}$ & Acanthaceae \\
\hline 5 & Bidens pilosa $\mathrm{L}^{*}$ & Asteraceae \\
\hline 6 & Brachiaria decumbens Stapf. ${ }^{* * *}$ & Poaceae \\
\hline 7 & Brachiaria eminii (Mez) Robyns ${ }^{* *}$ & Poaceae \\
\hline 8 & Brachiaria platynota (Schum.) Robyns ${ }^{* * *}$ & Poaceae \\
\hline 9 & Clerodendrum rotundifolium ${ }^{*}$ & Verbenaceae \\
\hline 10 & Commelina diffusa Burm. f.** & Commelinaceae \\
\hline 11 & Conyza sumatrensis Retz. ex Walker* & Asteraceae \\
\hline 12 & Cyathula uncinulata (Schrad.) Schinz. ${ }^{* *}$ & Amaranthaceae \\
\hline 13 & Cynodon dactylon $\mathrm{L}^{* *}$ & Poaceae \\
\hline 14 & Cyperus rigidifolius Steud. ${ }^{* * *}$ & Cyperaceae \\
\hline 15 & Cyperus rotundifolius Steud. ${ }^{* * *}$ & Cyperaceae \\
\hline 16 & Desmodium barbatum (L.) Benth. var. procumbens Schub. ${ }^{* * *}$ & Papilionoideae \\
\hline 17 & Desmodium salicifolium (Poir) ${ }^{* * *}$ & Papilionoideae \\
\hline 18 & Desmodium setigerum (E. Mey) Benth ${ }^{* * *}$ & Papilionoideae \\
\hline 19 & Desmodium setigerum (E. Mey) Benth. ${ }^{* * *}$ & Papilionoideae \\
\hline 20 & Dichondra repens J. R. \& G. Forst.*** & Convolvulaceae \\
\hline 21 & Dichondra repens G. R. \& G. Forst. ${ }^{* * *}$ & Convolvulaceae \\
\hline 22 & Dichondra repens J. R. \& G. Forst.*** & Convolvulaceae \\
\hline 23 & Galinsoga parviflora Cav.* & Asteraceae \\
\hline 24 & Hibiscus sp. ${ }^{* * *}$ & Malvaceae \\
\hline 25 & Hyparrhenia filipendula (Hochst. Ex Steud.) Stapf.*** & Poaceae \\
\hline 26 & Indigofera spicata Forssk.*** & Papilionoideae \\
\hline 27 & Indigofera spicata Forssk. ${ }^{* * *}$ & Papilionoideae \\
\hline 28 & Justicia matamensis (Schweinf.) Oliv. ${ }^{* * *}$ & Acanthaceae \\
\hline 29 & Kyllinga bulbosa P. Beauv.* & Cyperaceae \\
\hline 30 & Leonotis nepetifolia (L.) Ait ${ }^{* *}$ & Lamiaceae \\
\hline 31 & Mariscus sumatrensis (Retz) Rayn. ${ }^{* * *}$ & Cyperaceae \\
\hline 32 & Mariscus sumatrensis (Retz.) J. Rayn. ${ }^{* * *}$ & Cyperaceae \\
\hline 33 & Monechma subsessile (Oliv.) C.B. Cl. ${ }^{* * *}$ & Acanthaceae \\
\hline 34 & Neonotonia wightii (Wight \& Arn.) Lackey*** & Papilionoideae \\
\hline 35 & Neonotonia wightii (Wight \& Arn.) Lackey ${ }^{* *}$ & Papilionoideae \\
\hline 36 & Ocimum suave Willd. ${ }^{* *}$ & Lamiaceae \\
\hline 37 & Pennisetum clandestinum Chiov. ${ }^{*}$ & Poaceae \\
\hline 38 & Phyllanthus pseudoniruri Muell. Arg. ${ }^{* *}$ & Euphorbiaceae \\
\hline 39 & Pycreus nitidus (Lam.) J. Rayn. ${ }^{* * *}$ & Cyperaceae \\
\hline 40 & Rubia cordifolia $\mathrm{L}^{* * *}$ & Rubiaceae \\
\hline 41 & Ruellia patula Jacq. ${ }^{*}$ & Acanthaceae \\
\hline 42 & Setaria homonyma (Steud.) Chiov.* & Poaceae \\
\hline 43 & Setaria sp. ${ }^{*}$ & Gramineae \\
\hline 44 & Sida rhombifolia L. ${ }^{* *}$ & Malvaceae \\
\hline 45 & Sporobolus pyramidalis P. Beauv. ${ }^{* * *}$ & Poaceae \\
\hline 46 & Tagetes minuta** & Poaceae \\
\hline 47 & Triumfetta rhomboidea Jacq. ${ }^{* * *}$ & Tiliaceae \\
\hline
\end{tabular}

${ }^{*}$ Species that occurred under the tree canopies; ${ }^{* *}$ species that occurred in both niches; ${ }^{* * *}$ species that occurred outside the tree canopies. 
TABle 5: Populations of 11 plant species recorded under canopies of A. sieberiana trees in Songa pastures, southern Rwanda.

\begin{tabular}{lcccccccccccccccccc}
\hline Species\tree no. & 1 & 2 & 3 & 4 & 5 & 6 & 7 & 8 & 9 & 10 & 11 & 12 & 13 & 14 & 15 & 16 & Mean \\
\hline Setaria homonyma & 683 & 1037 & 115 & 806 & 972 & 637 & 1210 & 395 & 528 & 478 & 1001 & 240 & 826 & 816 & 594 & 756 & 693 \\
Tagetes minuta & 525 & 213 & 321 & 80 & 304 & 250 & 129 & 107 & 215 & 420 & 347 & 291 & 226 & 185 & 336 & 183 & 258 \\
Galinsoga parviflora & 182 & 0 & 197 & 12 & 203 & 168 & 83 & 27 & 65 & 39 & 78 & 107 & 128 & 85 & 48 & 75 & 94 \\
Achyranthes aspera & 17 & 60 & 194 & 67 & 101 & 29 & 46 & 29 & 73 & 66 & 48 & 125 & 78 & 48 & 29 & 92 & 69 \\
Leonotis nepetifolia & 88 & 11 & 38 & 8 & 71 & 59 & 32 & 90 & 74 & 54 & 27 & 46 & 56 & 82 & 96 & 63 & 56 \\
Asystasia gangetica & 91 & 24 & 12 & 0 & 26 & 37 & 31 & 26 & 9 & 28 & 18 & 5 & 16 & 32 & 26 & 30 & 26 \\
Bidens pilosa & 0 & 0 & 0 & 16 & 0 & 4 & 0 & 0 & 1 & 1 & 0 & 0 & 0 & 0 & 0 & 0 & 1 \\
Cyathula uncinulata & 0 & 13 & 0 & 0 & 0 & 0 & 0 & 0 & 3 & 0 & 0 & 0 & 4 & 0 & 0 & 0 & 1 \\
Rubia cordifolia & 0 & 0 & 1 & 0 & 0 & 0 & 0 & 0 & 0 & 1 & 1 & 2 & 0 & 0 & 5 & 0 & 1 \\
Conyza sumatrensis & 0 & 0 & 1 & 0 & 0 & 0 & 0 & 0 & 0 & 0 & 0 & 2 & 0 & 0 & 0 & 0 & 0.2 \\
Acacia sieberiana & 0 & 0 & 0 & 0 & 0 & 0 & 0 & 0 & 1 & 0 & 0 & 0 & 1 & 0 & 0 & 0 & 0.1 \\
\hline
\end{tabular}

instance, competition is frequently weakened and vice versa for facilitation under conditions of abiotic stress $[61,62]$ and disturbance such as grazing [63]. Facilitation could particularly benefit resource-demanding "acquisitive" species, likely of higher quality as forage due to higher nutrient content and lower content of structural and defensive compounds [55].

Simpson's index values under the canopy were high and ranged from 0.88 to 0.97 implying a high level of plant diversity. Some new species under tree crowns invaded the pastures and replaced grasses originally managed for cattle grazing. These species are usually found in agricultural fields and examples include Bidens pilosa, Conyza sumatrensis, and Tagetes minuta. There is likelihood that alien plant species, which are likely more competitive than the pasture species [64], have attracted an even higher animal and microbial diversity [65] thereby increasing the overall landscape biodiversity in the pastures. Unfortunately these alien plant species, most of which are annual herbs, seemed unpalatable to cattle since they remained intact throughout the rainy season at the end of which they died a natural death. The presence of $A$. sieberiana trees in the pastures and its association with nonpalatable invasive plant species, therefore, results in the reduction of effective pasture area that is used to produce cattle basal feed, the grasses.

Setaria homonyma which dominated the area under tree canopy was absent in the pasture area away from tree canopies. This may be attributed to it being a shade demanding grass species. Its exclusive occupation under the canopy may indicate how the light conditions under canopy are very important in determining plant dominance. The rest of the species identified under the tree canopy did not occur in the open pasture but did occur in open agricultural fields in which case they are weeds or grow in other frequently disturbed areas. This is very interesting because agricultural lands are usually exposed to direct solar radiation and plant species in them are expected to be light demanders. On the other hand, those occurring under A. sieberiana trees are expected to be shade bearers since they received solar radiation reduced as low as $38 \%$ of the amount in the open areas. Despite being very important, light levels may therefore not be the only major cause of change in plant species composition under $A$. sieberiana tree crowns. Other factors such as soil moisture and water stress may play a great role as well. Trees are known to take up environmental resources in their vicinity thereby outcompeting annual plant species growing near them [66-68].

The soils under the canopy appeared as a disturbed, loose and with annually dying and decaying plants. This happens every year leaving the floor bare or semibare during the dry seasons with plants emerging again in the majority of cases during the early next rain season. This microhabitat enables a suite of species that are shade tolerant and not adapted to strong competition as occurred in the grass dominated open pasture outside the tree crowns, thus enriching overall biodiversity [69].

3.5. Lack of Natural Regeneration in A. sieberiana. It is particularly surprising that $A$. sieberiana had only one seedling recorded once in the whole pasture area (310 ha) and no saplings were observed. Poor regeneration in native trees has been raised as a concern and might be exacerbated by climate change. This casts doubt on the survival and population increase in $A$. sieberiana outside deliberate human intervention. One of the most likely causes of poor regeneration in this species is probably the total absence of wild fires. Wild fires characterize savannah woodlands of Africa and play a role in the regeneration of trees through breaking seed dormancy $[16,70]$. Many studies have confirmed a dormancy relief in legume seeds after fire [71-79].

On environmental protection grounds, bush fire is banned on the Rwandan territory. This may be justified for soil and water conservation purposes. However, some plant species may be disadvantaged as long as natural regeneration is concerned. The distribution of plant species is often thought to be dependent upon environmental effects on germination and seedling establishment [80]. The connection between germination, seedling survival, and distribution of leaves opens the possibility that other environmental factors that affect germination success may influence the distribution and existence of the species [81]. Poor to no regeneration was also noted in other Rwandan acacias studied recently, especially where soils have never been disturbed. While trampling and browsing by grazing animals in the pastures could also lead to the lack of recruitment by $A$. sieberiana 


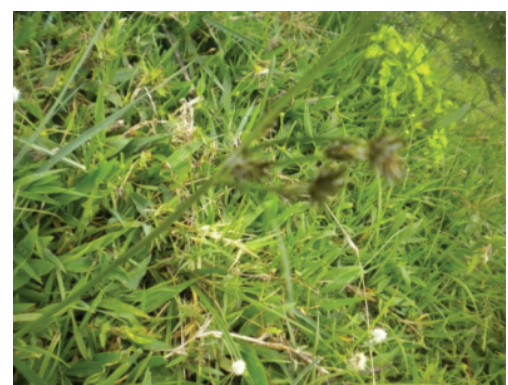

(a)

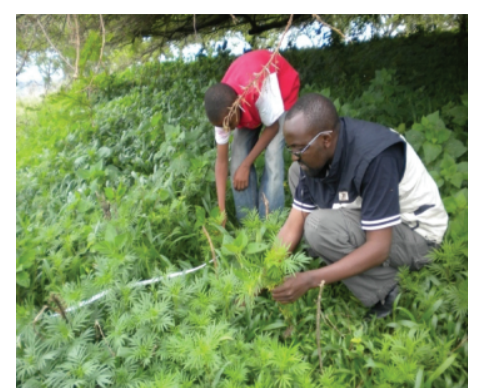

(b)

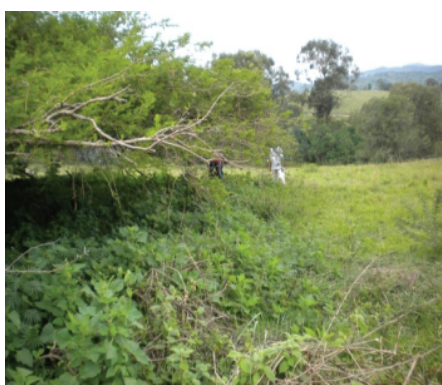

(c)

FIGURE 2: Diversity and life forms of plant species identified under Acacia sieberiana trees and in its surroundings: (a) open pastures, (b) under tree canopy, and (c) both under and away from the tree canopy.

trees, the area surrounding the pastures where animals are not allowed to graze freely does not have A. sieberiana saplings as well.

\section{Conclusions}

Circumstances that lead to isolated trees in Rwanda are increasing due to ecosystem fragmentation and changes in land use. This requires proper policy on the management of both the trees and the ecosystems. The knowledge generated in this study is relevant both for policy makers and pasture managers. Some useful characteristics of crown architecture in A. sieberiana that determine its shading intensity, plant species, and diversity under their canopy, which had never been considered important and thus not quantified, have now been characterized. These include branch length, heights of the crown base above the ground, the number of branches, and height of branch tips above the ground. Light levels under A. sieberiana tree canopies at $0,7.5$, and $15 \mathrm{~m}$ from the tree base were found to be 38,60 , and $85 \%$ (average $61 \%$ ) of its magnitude in the open pastures, respectively. The three distances corresponded to the middle, halfway, and the periphery of $A$. sieberiana tree crown, respectively.

As observed, A. sieberiana trees have a positive influence on soil physical and chemical properties besides the already known value of providing fodder and shade for livestock, especially during dry seasons in arid and semiarid areas. Furthermore, some ecologically useful services can be made available by the presence of $A$. sieberiana trees in the pastures. The trees may increase biodiversity at landscape level. The amount of light was observed to influence species niche preference, but soil moisture and water stress (not assessed in this study) may also play a role in this respect. However, the trees shade the area under canopies thereby promoting the growth of plants seemingly unpalatable to livestock. This may reduce the effective pasture area that yields palatable grasses for livestock feeding. Grasses constitute the basal feed for the livestock. The area potential for producing palatable grass affected by one A. sieberiana tree/ha was observed to be $600 \mathrm{~m}^{2}$. At an average stocking recorded in this study of 3 trees/ha, the ground shaded by the tree crowns which would therefore not produce palatable grasses was $1,800 \mathrm{~m}^{2}(18 \%$ of one hectare).
Some studies are recommended to fill the gaps observed in this study. These include, losses in the yield of palatable grasses in relation to the shading effect of A. sieberiana trees, fodder quantity and quality of both the palatable grasses and A. sieberiana trees and if the latter can compensate for losses in the yield of palatable grasses encountered due to the presence of the trees in the pastures shelter value of $A$. sieberiana trees in the pasture, and the appropriate stocking of these in relation to palatable grass production.

\section{Acknowledgments}

This paper combines an M.S. thesis research and additional study on A. sieberiana at the National University of Rwanda (NUR). The authors sincerely thank the Swedish International Development Agency for funding this work through the National University of Rwanda Research Directorate. Very sincere and heartfelt thanks are due to the late Esron Munyanziza for his invaluable contribution to this study. May the Lord rest his soul in eternal peace. C. K. Ruffo's contribution in plant identification is highly valued.

\section{References}

[1] M. A. Gold, W. J. Rietveld, H. E. Garrett, and R. F. fisher, "Agroforestry nomenclature, concepts, and practices for the USA," in North American Agroforestry: An Integrated Science and Practice, H. E. Garrett, W. J. Rietveld, and R. F. Fisher, Eds., pp. 63-76, ASA, Madison, Wis, USA, 2000.

[2] E. Munyanziza, "Agroforestry systems, tree species composition and its effect on ectomycorrhizal fungal diversity in Africa," in Modern Approaches and Innovations in Soil Management, D. J. Bagyaraj, A. Verma, K. K. Khanna, and H. K. Kehri, Eds., pp. 91-103, Rastogi Publications, Meerrut, India, 1999.

[3] S. Díaz, J. G. Hodgson, K. Thompson et al., "The plant traits that drive ecosystems: evidence from three continents," Journal of Vegetation Science, vol. 15, no. 3, pp. 295-304, 2004.

[4] D. J. Eldridge and V. N. L. Wong, "Clumped and isolated trees influence soil nutrient levels in an Australian temperate box woodland," Plant and Soil, vol. 270, no. 1, pp. 331-342, 2005.

[5] S. Kidanu, T. Mamo, and L. Stoosnijder, "Biomass production of Eucalyptus boundary and their effect on crop productivity on Ethiopian highland Vertisols," Agroforestry Systems, vol. 63, pp. 281-290, 2005. 
[6] J. M. Albaugh, P. J. Dye, and J. S. King, "Eucalyptus and water use in South Africa," International Journal of Forestry Research, vol. 2013, Article ID 852540, 11 pages, 2013.

[7] D. I. Forrester, S. Theiveyanathan, J. J. Collopy, and N. E. Marcar, "Enhanced water use efficiency in a mixed Eucalyptus globulus and Acacia mearnsii plantation," Forest Ecology and Management, vol. 259, no. 9, pp. 1761-1770, 2010.

[8] L. B. Guo, R. E. H. Sims, and D. J. Horne, "Biomass production and nutrient cycling in Eucalyptus short rotation energy forests in New Zealand. I: biomass and nutrient accumulation," Bioresource Technology, vol. 85, no. 3, pp. 273-283, 2002.

[9] R. B. Harrison, G. G. Reis, M. D. G. F. Reis, A. L. Bernardo, and D. J. Firme, "Effect of spacing and age on nitrogen and phosphorus distribution in biomass of Eucalyptus camaldulensis, Eucalyptus pellita and Eucalyptus urophylla plantations in southeastern Brazil," Forest Ecology and Management, vol. 133, no. 3, pp. 167-177, 2000.

[10] R. K. Gupta, Multipurpose Trees for Agroforestry and Wasteland Utilisation, International Science Publisher, New York, NY, USA, 1993.

[11] C. Huttel and J. L. Loumeto, "Effect of exotic tree plantations and site management on plant diversity," in Effect of Exotic Tree Plantations on Plant Diversity and Biological Soil Fertility in the Congo Savanna: With Special Reference to Eucalypts, F. Bernhard-Reversat, Ed., pp. 9-18, Center for International Forestry Research, Bogor, Indonesia, 2001.

[12] A. E. Hartemink, "Assessing soil fertility decline in the tropics using soil chemical data," Advances in Agronomy, vol. 89, pp. 179-225, 2006.

[13] K. I. Paul, P. J. Polglase, J. G. Nyakuengama, and P. K. Khanna, "Change in soil carbon following afforestation," Forest Ecology and Management, vol. 168, no. 1-3, pp. 241-257, 2002.

[14] N. Lisanework and A. Michelsen, "Allelopathy in agroforestry systems: the effects of leaf extracts of Cupressus lusitanica and three Eucalyptus spp. on four Ethiopian crops," Agroforestry Systems, vol. 21, no. 1, pp. 63-74, 1993.

[15] S. J. Milton and W. R. J. Dean, "How useful is the keystone species concept, and can it be applied to Acacia erioloba in the Kalahari Desert?" Zeitschrift für Okologie und Naturschutz, vol. 4, no. 3, pp. 147-156, 1995.

[16] FAO, "Global forest resource assessment, 2005. FAO forestry paper 147. Kenya forestry service, 2009," in A Guide to on-Farm Eucalyptus Growing in Kenya, Kenya Forestry Service, Nairobi, Kenya, 2006.

[17] C. J. Borough, "Control of soil acidity," in Trees for Rural Australia, K. W. Cremer, Ed., pp. 34-41, Inkata Press, Melbourne, Australia, 1990.

[18] G. Cadisch, P. de Willigen, D. Suprayogo, D. C. Mobs, M. van Noordwijk, and E. C. Rowe, "Catching and competing for mobile nutrients in soils," in Below Ground Interactions in Tropical Agroecosysytems: Concepts and Models with Multiple Plant Components, M. van Noordwijk, G. Cadisch, and C. K. Ong, Eds., pp. 171-191, CABI, Cambridge, UK, 2004.

[19] M. van Noordwijk, G. Lawson, A. Soumare, J. Groot Jr., and K. Hairiah, "Root distribution of trees and crops: competition and/or complementarity," in Tree-Crop Interactions: A Physiological Approach, C. K. Ong and P. Huxley, Eds., pp. 319-364, Wallingford, UK, CABI edition, 1996.

[20] P. J. Ryan and J. W. McGarity, "The nature and spatial variability of soil properties adjacent to large forest eucalypts," Soil Science Society of America Journal, vol. 47, no. 2, pp. 286-293, 1983.
[21] D. J. Munnich, P. C. Simpson, and H. Nicol, "A survey of native grasses in the Goulburn district and factors influencing their abundance," Rangeland Journal, vol. 13, pp. 118-129, 1991.

[22] C. B. Pandey and D. K. Sharma, "Residual effect of nitrogen on rice productivity following tree removal of Acacia nilotica in a traditional agroforestry system in central India," Agriculture, Ecosystems and Environment, vol. 96, no. 1-3, pp. 133-139, 2003.

[23] H. H. Hansen, L. Sanou, and B. M. I. Nacoulma, "Tree leaves in the diet of free ranging ruminants in three areas of Burkina Faso," Livestock Research for Rural Development, vol. 20, article 33, 2008.

[24] J. J. Ewel, "Natural systems as models for the design of sustainable systems of land use," Agroforestry Systems, vol. 45, no. 1-3, pp. 1-21, 1999.

[25] A. Woodward and J. D. Reed, "The influence of polyphenolics on the nutritive value of browse: a summary of research conducted at ILCA," International Livestock Centre for Africa Bulletin, vol. 35, pp. 2-11, 1989.

[26] R. Tiedemann and J. O. Klemmedson, "Nutrient availability in desert grassland soils under mesquite (Prosopis juliflora) trees and adjacent open areas," Soil Science Society of America Proceedings, vol. 37, pp. 107-111, 1993.

[27] A. J. Belsky, S. M. Mwonga, R. G. Amundson, J. M. Duxbury, and A. R. Ali, "Comparative effects of isolated trees on their undercanopy environments in high- and low-rainfall savannas," Journal of Applied Ecology, vol. 30, no. 1, pp. 143-155, 1993.

[28] R. Everett, S. Sharrow, and D. Thran, "Soil nutrient distribution under and adjacent to singleleaf pinyon crowns," Soil Science Society of America Journal, vol. 50, no. 3, pp. 788-792, 1986.

[29] A. J. Dowling, A. A. Webb, and J. C. Scanlan, "Surface soil chemical and physical patterns in a brigalow-Dawson gum forest, central Queensland," Australian Journal of Ecology, vol. 11, no. 2, pp. 155-162, 1986.

[30] K. M. Dunham, "Litterfall, nutrient-fall and production in an Acacia albida woodland in Zimbabwe," Journal of Tropical Ecology, vol. 5, no. 2, pp. 227-238, 1989.

[31] H. B. Waldon, M. B. Jenskins, R. A. Virginia, and E. E. Harding, "Characteristics of woodland rhizobial populations from surface- and deep-soil enviroments of the Sonoran Desert," Applied and Environmental Microbiology, vol. 55, no. 12, pp. 3058-3064, 1989.

[32] S. Puri, S. Singh, and A. Kumar, "Growth and productivity of crops in association with an Acacia nilotica tree belt," Journal of Arid Environments, vol. 27, no. 1, pp. 37-48, 1994.

[33] J. B. Nduwayezu, C. K. Ruffo, V. Minani, E. Munyaneza, and S. Nshutiyayesu, Know Some Useful Trees and Shrubs for Agricultural and Pastoral Communities of Rwanda, IRST, Butare, Rwanda; Pallotti Press, Kigali, Rwanda, 2009.

[34] M. Manzi, J. Owino Junga, C. Ebong, and R. O. Mosi, "Factors affecting pre and post-weaning growth of six cattle breed groups at songa research station in Rwanda," Livestock Research for Rural Development, vol. 24, article 68, 2012.

[35] G. Delepierre, "Les regions agricoles du Rwanda," Bulletin Agricole du Rwanda, vol. 8, pp. 216-225, 1975.

[36] J. R. Okalebo, K. W. Gathua, and P. L. Woomer, Laboratory Methods of Soil Analysis: A Working Manual, TSBF-CIAT and SAGRED Africa, Nairobi, Kenya, 2nd edition, 2002.

[37] P. E. V. Charman and M. M. Roper, "Soil organic matter," in Soils: Their Properties and Management, pp. 260-269, Oxford University Press, Melbourne, Australia, 2000. 
[38] A. Golchin, P. Clarke, J. M. Oades, and J. O. Skjemstad, "The effects of cultivation on the composition of organic matter and structural stability of soils," Australian Journal of Soil Research, vol. 33, no. 6, pp. 975-993, 1995.

[39] P. A. Sanchez, "Science in agroforestry," Agroforestry Systems, vol. 30, no. 1-2, pp. 5-55, 1995.

[40] M. C. Sirois, H. A. Margolis, and C. Camiré, "Influence of remnant trees on nutrients and fallow biomass in slash and burn agroecosystems in Guinea," Agroforestry Systems, vol. 40, no. 3, pp. 227-246, 1998.

[41] A. Verdoodt and E. van Ranst, "The soil information system of Rwanda: a useful tool to identify guidelines towards sustainable land management," Africa Focus, vol. 19, pp. 69-92, 2006.

[42] P. Vander Zaag, R. S. Yost, B. B. Trangmar, K. Hayashi, and R. L. Fox, "An assessment of chemical properties for soils of Rwanda with the use of geostatistical techniques," Geoderma, vol. 34, no. 3-4, pp. 293-314, 1984.

[43] K. R. Helyar, P. D. Cregan, and D. L. Godyn, "Soil acidity in New South Wales-current $\mathrm{pH}$ values and estimates of acidification rates," Australian Journal of Soil Research, vol. 28, no. 4, pp. 523537, 1990.

[44] B. Wilson, "Influence of scattered paddock trees on surface soil properties: a study of the Northern tablelands of NSW," Ecological Management and Restoration, vol. 3, no. 3, pp. 211219, 2002.

[45] A. Young, Agroforestry for Soil Management, CABI, Wallingford, UK, 1997.

[46] A. J. Belsky, "Influences of trees on savanna productivity: tests of shade, nutrients, and tree-grass competition," Ecology, vol. 75, no. 4, pp. 922-932, 1994.

[47] C. Orwa, A. Mutua, R. Kindt, R. Jamnadass, and S. Anthony, "Agroforestree Database tree reference and selection guide version 4.0," 2009, http://www.worldagroforestry.org/sites/ treedbs/treedatabases.asp.

[48] G. P. Berlin and J. Cho, "Light, moisture and nutrient use by plants," in The Silvicultural Basis for Agroforestry Systems, M. S. Ashton and F. Montagnini, Eds., pp. 9-39, CRC Press, Washington, DC, USA, 2000.

[49] P. M. S. Ashton and G. P. Berlyn, "Leaf adaptations of some Shorea species to sun and shade," New Phytologist, vol. 121, no. 4, pp. 587-596, 1992.

[50] P. M. S. Ashton and G. P. Berlyn, "A comparison of leaf physiology and anatomy of Quercus (section ErythrobalanusFagaceae) species in different light environments," The American Journal of Botany, vol. 81, no. 5, pp. 589-597, 1994.

[51] H. K. Mokoboki, L. R. Ndlovu, and M. M. Malatje, "Intake and relative palatability indices of Acacia species fed to sheep and goats," Agroforestry Systems, vol. 81, no. 1, pp. 31-35, 2011.

[52] E. N. Chidumayo, "Demographic implications of life history stage characteristics in two African acacias at a Makeni savanna plot in Zambia," Journal of Plant Ecology, vol. 1, pp. 217-225, 2008.

[53] C. Dupraz and S. M. Newman, "Temperate agroforestry systems," in Temperate Agroforestry: The European Way, A. M. Gordon and S. M. Newman, Eds., pp. 181-236, CABI, Wallingford, UK, 1997.

[54] M. P. González-Hernández and M. J. R. Lorenzo, "Pasture production and tree growth in agroforestry systems of northwest Spain," in Ecological Basis of Agroforestry, D. R. Batish, R. K. Kohli, S. Jose, and H. P. Singh, Eds., pp. 361-375, CRC Press, Boca Raton, Fla, USA, 2008.
[55] J. Sircely and S. Naeem, "Relationships of overstory trees and shrubs with forage species portray ecosystem service interactions in smallholder fallows," Agroforestry Systems, vol. 87, pp. 451-464, 2013.

[56] S. Díaz, D. A. Wardle, and A. Hector, "Incorporating biodiversity in climate change mitigation initiatives," in Biodiversity, Ecosystem Functioning, and Human Wellbeing-An Ecological and Economic Perspective, S. Naeem, D. E. Bunker, A. Hector, M. Loreau, and C. Perrings, Eds., pp. 149-166, Oxford University Press, Oxford, UK, 2009.

[57] I. J. Wright, P. B. Reich, M. Westoby et al., "The worldwide leaf economics spectrum," Nature, vol. 428, no. 6985, pp. 821-827, 2004.

[58] R. Aerts and F. S. Chapin III, "The mineral nutrition of wild plants revisited: a re-evaluation of processes and patterns," Advances in Ecological Research, vol. 30, pp. 1-67, 1999.

[59] H. G. Jung and M. S. Allen, "Characteristics of plant cell walls affecting intake and digestibility of forages by ruminants," Journal of Animal Science, vol. 73, no. 9, pp. 2774-2790, 1995.

[60] K. J. Moore and H. G. Jung, "Lignin and fiber digestion," Journal of Range Management, vol. 54, no. 4, pp. 420-430, 2001.

[61] R. W. Brooker, F. T. Maestre, R. M. Callaway et al., "Facilitation in plant communities: the past, the present, and the future," Journal of Ecology, vol. 96, no. 1, pp. 18-34, 2008.

[62] R. M. Callaway, R. W. Brooker, P. Choler et al., "Positive interactions among alpine plants increase with stress," Nature, vol. 417, no. 6891, pp. 844-848, 2002.

[63] P. Graff, M. R. Aguiar, and E. J. Chaneton, "Shifts in positive and negative plant interactions along a grazing intensity gradient," Ecology, vol. 88, no. 1, pp. 188-199, 2007.

[64] Convention on Biodiversity, "Forest resilience, biodiversity and climate change," CBD Technical Series No 43, 2009.

[65] S. J. DeWalt, S. K. Maliakal, and J. S. Denslow, "Changes in vegetation structure and composition along a tropical forest chronosequence: implications for wildlife," Forest Ecology and Management, vol. 182, no. 1-3, pp. 139-151, 2003.

[66] L. O. Z. Onyewotu, M. A. Ogigirigi, and C. J. Stigter, "A study of competitive effects between a Eucalyptus camaldulensis shelterbelt and an adjacent millet (Pennisetum typhoides) crop," Agriculture, Ecosystems and Environment, vol. 51, no. 3, pp. 281286, 1994.

[67] M. G. R. Cannell, M. van Noordwijk, and C. K. Ong, “The central agroforestry hypothesis: the trees must acquire resources that the crop would not otherwise acquire," Agroforestry Systems, vol. 34, no. 1, pp. 27-31, 1996.

[68] E. C. Rowe, M. van Noordwijk, D. Suprayogo, and G. Cadisch, "Nitrogen use efficiency of monoculture and hedgerow intercropping in the humid tropics," Plant and Soil, vol. 268, no. 1, pp. 61-74, 2005.

[69] O. A. Leistner, "The subcanopy flora in the dynamics of the Kalahari Thornveld," in The Biodiversity of African Plants Proceedings, 14th AETFAT Congress, 22-27 August 1994, Wageningen, The Netherlands, L. J. G. van der Maesen, X. M. van der Burgt, and J. M. van Medenbach de Rooy, Eds., pp. 163-179, Kluwer Academic, Boston, Mass, USA, 1996.

[70] E. M. Lind and M. E. S. Morisson, East African Vegetation, Longman, London, UK, 1974.

[71] R. M. Jones, "Preliminary studies of the germination of seed of Acacia cyclops and Acacia cynbophylla," South African Journal of Science, vol. 59, pp. 296-298, 1963. 
[72] E. N. Sabiiti and R. W. Wein, "Fire and Acacia seeds: a hypothesis of colonization success," Journal of Ecology, vol. 75, no. 4, pp. 937-946, 1987.

[73] P. J. Pieterse and A. L. P. Cairns, "The effect of fire on an Acacia longifolia seed bank in the south-western Cape," South African Journal of Botany, vol. 52, no. 3, pp. 233-236, 1986.

[74] T. D. Auld and M. A. O'Connell, "Changes in predispersal seed predation levels after fire for two Australian legumes, Acacia elongata and Sphaerolobium vimineum," Oikos, vol. 54, no. 1, pp. 55-59, 1989.

[75] H. A. Omer, "The effect of burning on the viability of five Acacia species," Sudan Silva, vol. 20, no. 3, pp. 20-22, 1975.

[76] J. M. Lock, "Vegetation studies in Queen Elizabeth National Park, Uganda," Agriculture Consulting Technical Assistance to Uganda Institute of Ecology Project No. 4100.337.42.41, 1988.

[77] R. A. Bradstock and T. D. Auld, "Soil temperatures during experimental bushfires in relation to fire intensity: consequences for legume germination and fire management in southeastern Australia," Journal of Applied Ecology, vol. 32, no. 1, pp. 76-84, 1995.

[78] D. Teketay, "Germination ecology of twelve indigenous and eight exotic multipurpose leguminous species from Ethiopia," Forest Ecology and Management, vol. 80, no. 1-3, pp. 209-223, 1996.

[79] B. A. Mbalo and E. T. F. Witkowski, "Tolerance to soil temperatures experienced during and after the passage of fire in seeds of Acacia karroo, A. tortilis and Chromolaena odorata: a laboratory study," South African Journal of Botany, vol. 63, no. 6, pp. 421425, 1997.

[80] P. A. Thompson, "A comparison of the germinative character of species of Caryophyllaceae collected in Central Germany," Journal Ecology, vol. 58, pp. 699-711, 1971.

[81] C. Chikono and J. S. Choinski Jr., “Thermotolerance characteristics of seeds from geographically isolated populations of the African tree Combretum apiculatum Sonder," African Journal of Ecology, vol. 30, no. 1, pp. 65-73, 1992. 

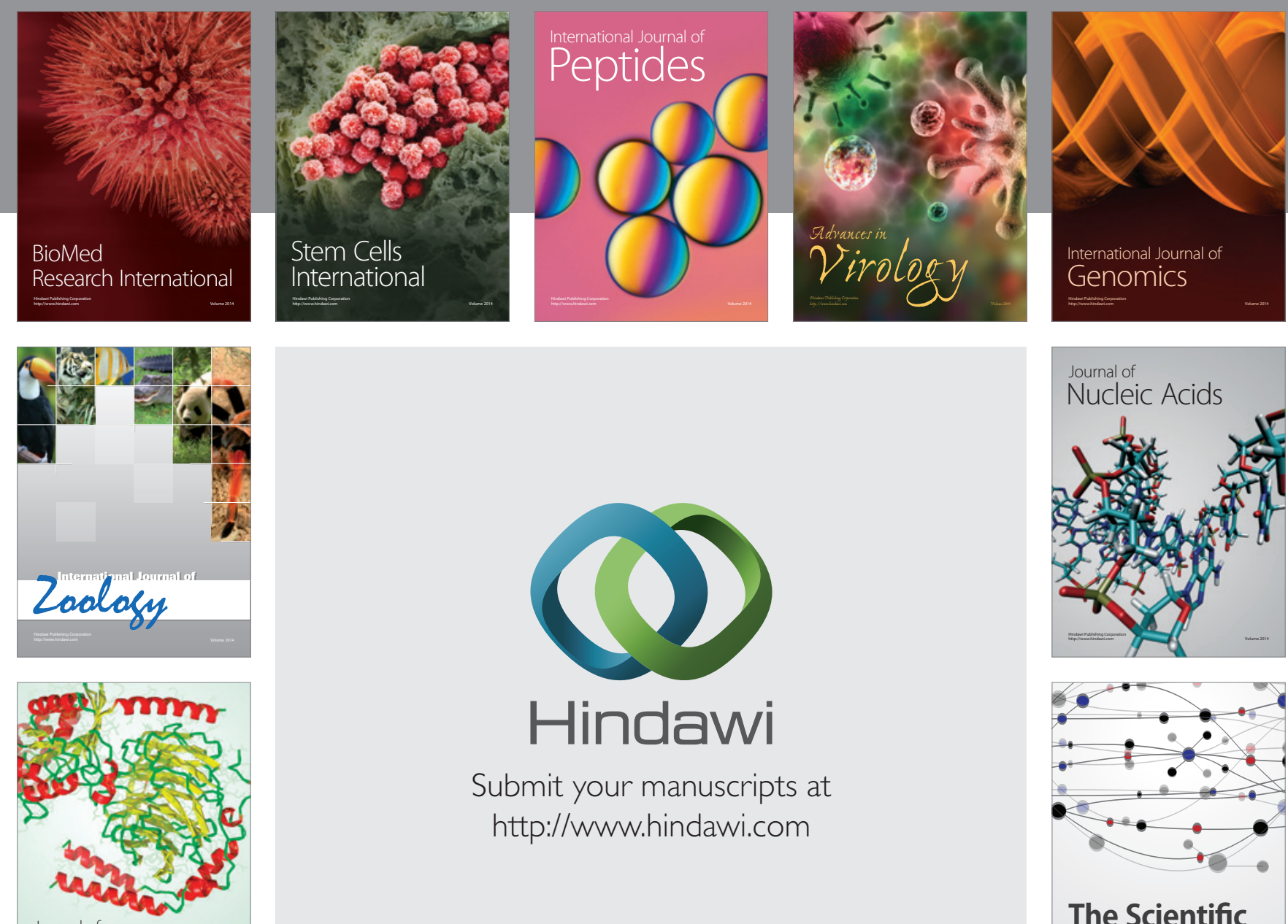

Submit your manuscripts at

http://www.hindawi.com

Journal of
Signal Transduction
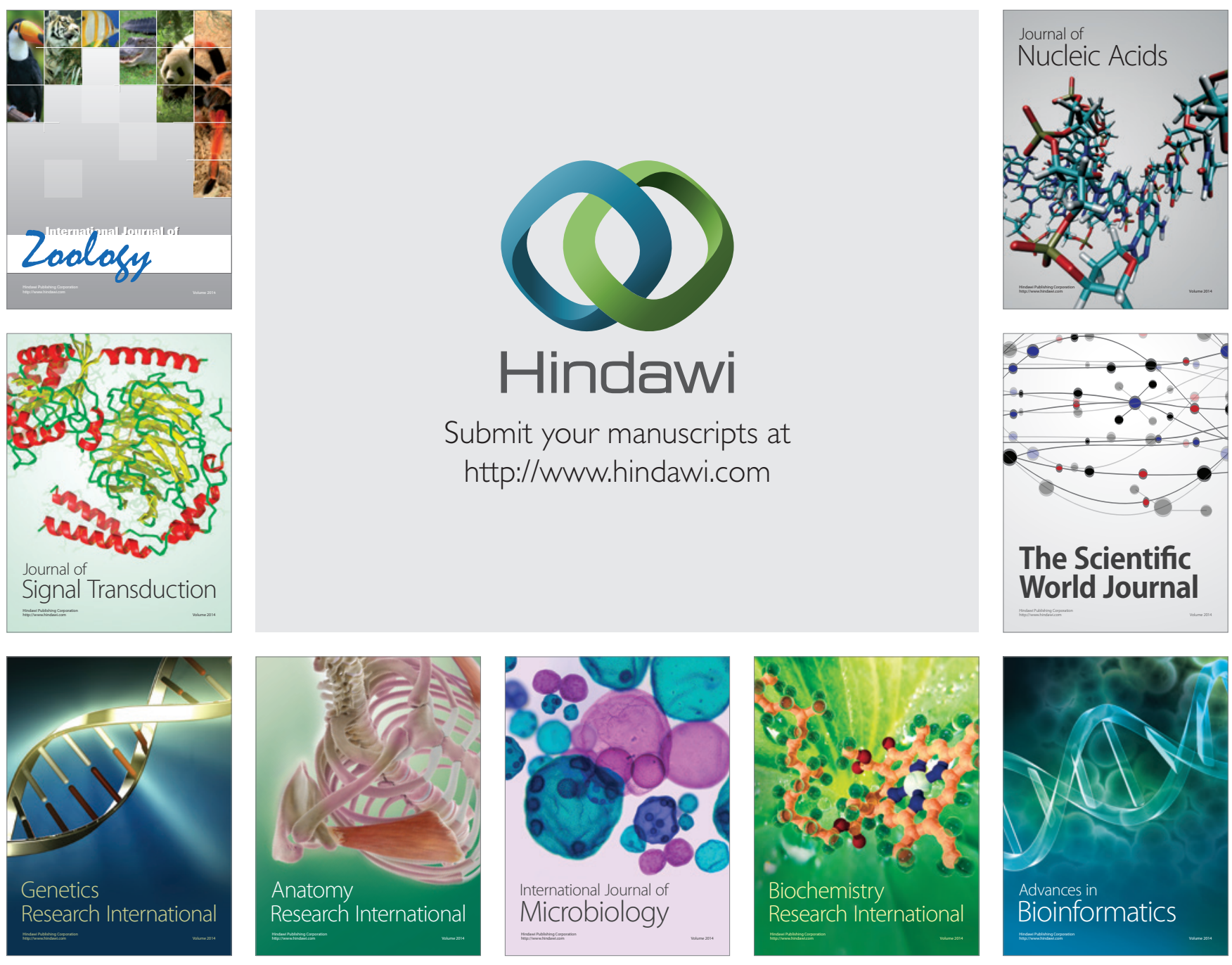

The Scientific World Journal
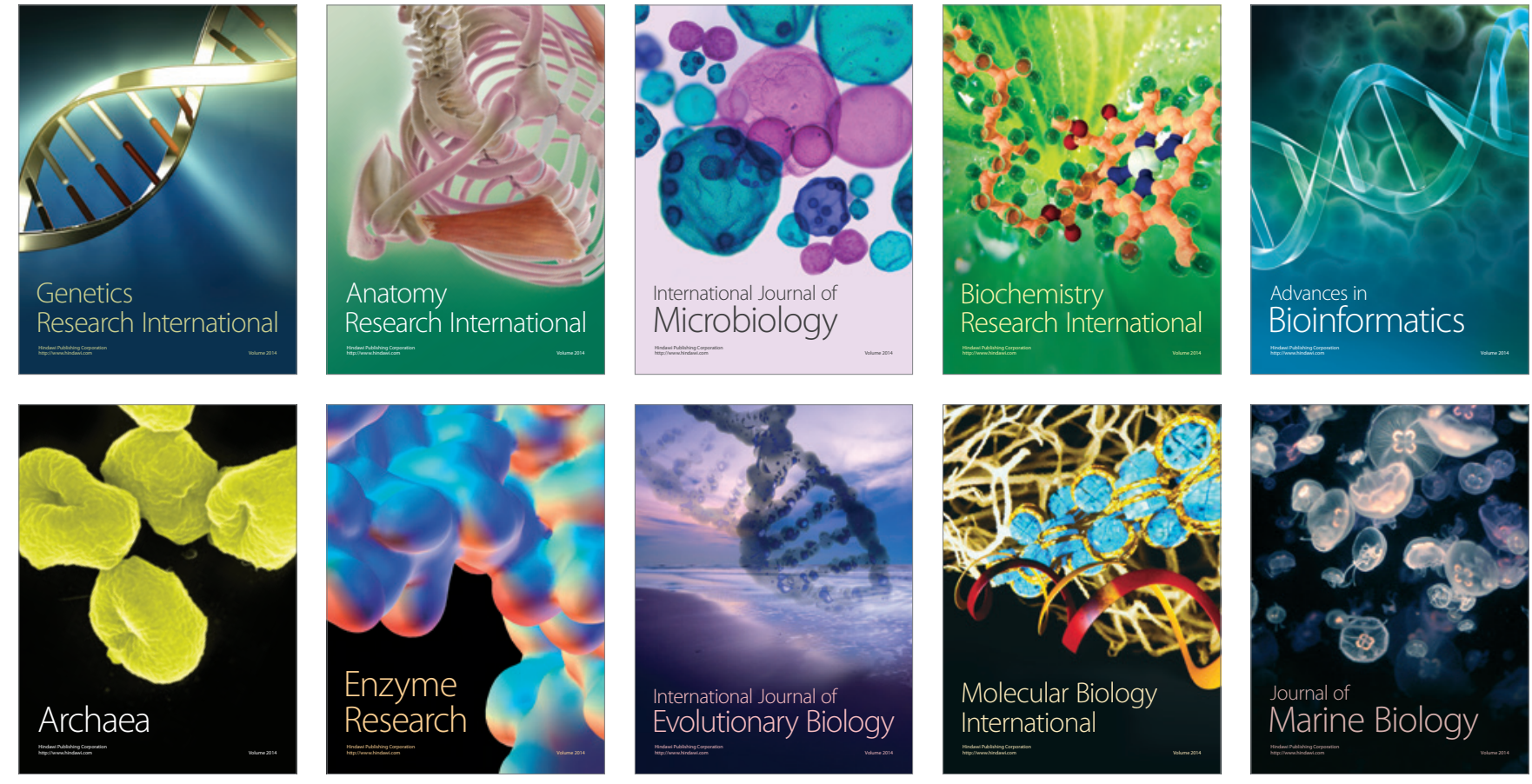